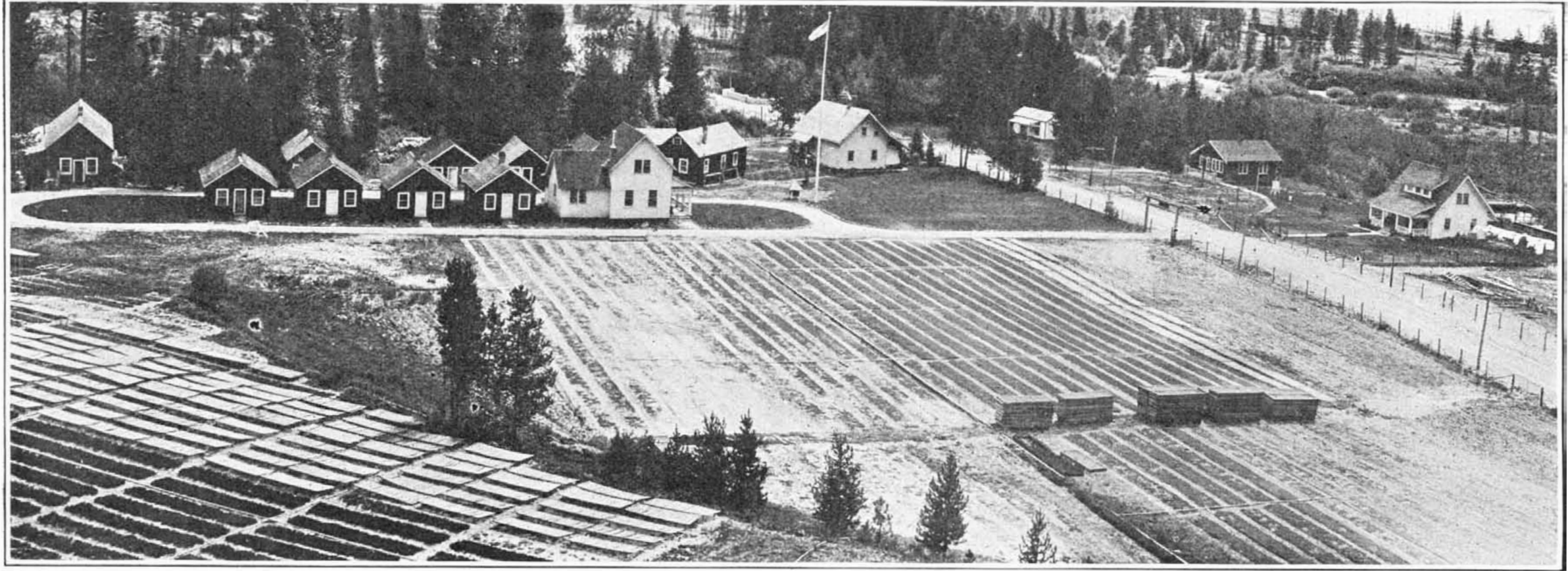

General view of the Sarenac Nursery seed beds, Lolo National Forest, Mont.

\title{
Our Reforestation Activities
}

Some Facts and Figures About Tree Planting on a Gigantic, Yet Still Insufficient, Scale

\author{
By Charles Frederick Carter
}

NOW that a comprehensive program for forest conservation has been formulated for the first time and submitted to Congress as the "Snell Bill," a brief inventory of our forest resources today and a summary of the efforts now being made to provide for the needs of tomorrow should be of interest, although such a survey is hardly flattering to the National vanity.

It is now forty-eight years since Congress first took cognizance of the necessity for Governmental action to conserve the Nation's forest resources by the passage of the timber culture act of 1873 ; thirty years since the first forest reserve law, designed to protect the sources of streams, was enacted; and twenty-four years since recommendations of the National Academy of Sciences, submitted pursuant to request from Congress, were formulated into what then seemed an adequate National forest policy. All this time we have continued to squander our forest resources with the prodigal folly

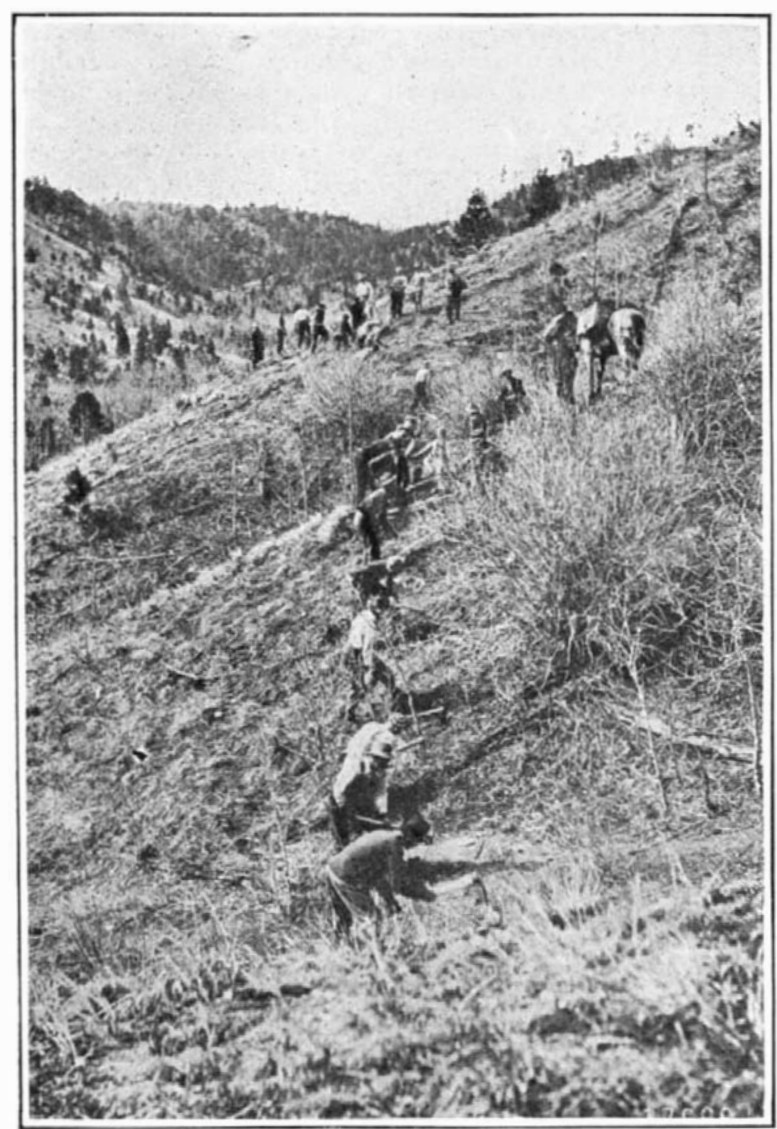

setting out yellow pine, Pike National Forest, Colo. of the proverbial drunken sailor until at last we are confronted with the knowledge that they will be exhausted within a few. years unless heroic measures are applied at once.

Figures from the National Forest Service fix the total original forest area of the United States at 822 , 238,000 acres, of which there remain approximately $463,000,000$ acres of nominal forest. But only 30 per cent, or $137,000,000$ acres is virgin forest. The rest includes $112,000,000$ acres of second-growth saw timber, $133,000,000$ acres of second-growth below saw-timber size and $81,000,000$ acres which have been devastated by wasteful methods of cutting and by repeated fires, on which nothing of value is growing or likely to grow without a huge expenditure for reforestation. This totally devastated area is equal to the combined areas of France, Germany, Belgium, Holland, Denmark, Switzerland, Spain and Portugal Besides the waste land there are approximately 245,000,000 acres bearing second-growth forest. In a large part of this forest wasteful cutting or excessive grazing have reduced production to a mere fraction of what it might be with proper handling. To convert such lands into valuable producing forests will, in many cases, involve expenditures as great as if the lands were devastated Of the meager remnant of merchantable timber at least 5,500,000 acres are cut over each year; and they are cut over much more closely than formerly with the result that after fires have killed out most of the young growth there is little or no chance for reproduction to start.

Destruction from various causes diminishes the visible supply even more rapidly than use. From 1915 to 1918 an average of $9,400,000$ acres of forest land were burned over each year: and in 1910 and 1919 the area was considerably larger. Storms, too, take their toll, a single cyclone on January 27, 1921 cutting a swath through the magnificent forest on the Olympic peninsula 30 miles wide and 75 miles long, destroying $8,000,000,000$ board feet of timber. Then the black pine beetle is destroying timber by the billions of feet in the Pacific Northwest

Stated in another way timber is being cut at the rate of $26,000,000,000$ cubic feet a year, or more than four times as fast as the new timber is growing; while that of saw-timber size is being cut and destroyed by fire, disease and insects at the rate of $56,000,000,000$ board feet a year, or more than five and a half times the growth of such material.

In view of such facts as these, efforts to conserve what timber is left and to provide for the future assume a lively interest; for the physical and economic well-being of everybody is intimately associated with adequate forest resources.

It is, perhaps, only natural that the uninitiated should imagine that forests would have to be restored by planting. Data from the U. S. Forest Service show that a total of 170,000 acres have been planted by the Service up to the end of June, $1920 ; 85,000$ acres additional by the State Forestry Departments, and 350,000 acres by private individuals and corporations in 19 states. Adding the estimated planting in Nebraska, Kansas, Illinois, the Dakotas, Missouri, and Oklahoma would swell the private planting to a total of 750,000 acres, or a little more than a million acres planted by all the agencies that have been operating in this field in the United States, from the time. when planting was first undertaken by the western settlers forty or fifty years ago, right down to the present time. The Snell Bill appropriates $\$ 1,000,000$ yearly for five years for reforesting denuded lands in the National Forests. As the average cost of planting is $\$ 10$ an acre, this would provide for the reforesting of 100,000 acres a year. This is regarded as the maximum practi-

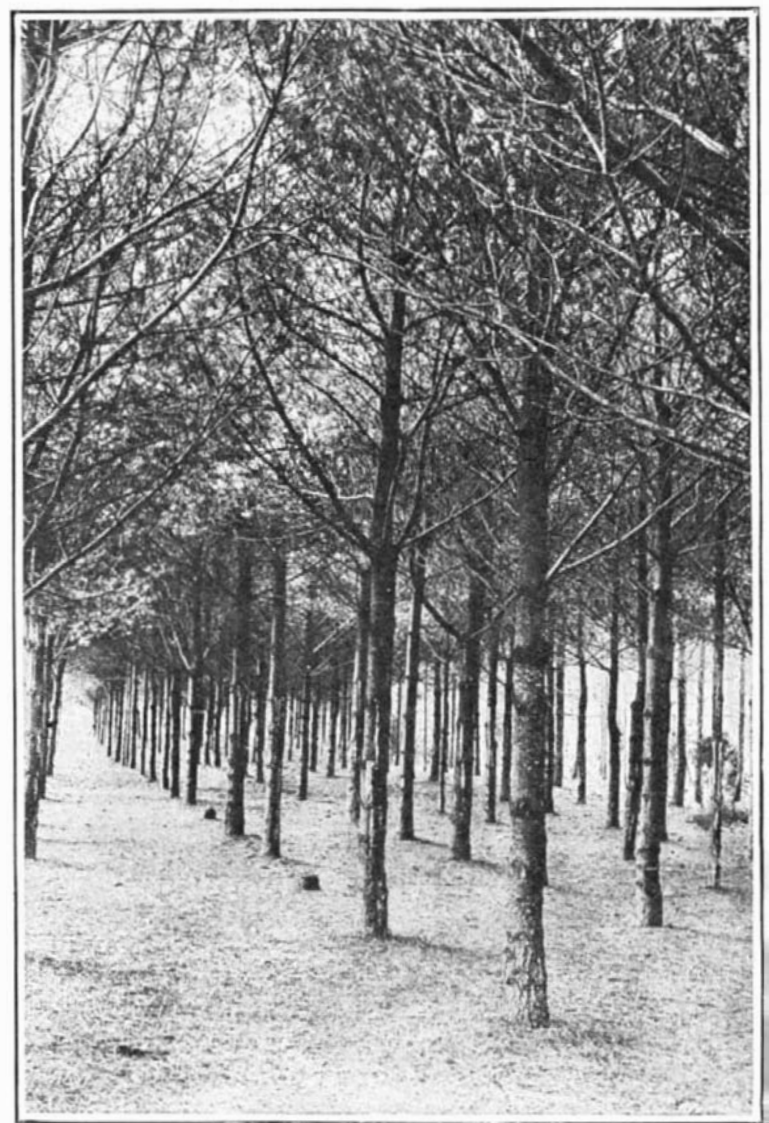

White pine plantation 22 years old, on bare sand in Rhode Island for reclamation purposes 
cable program by the National Forestry Program Committee representing professional foresters and a large number of organizations in terested in forest conservation, although an ideal program would be $1,000,000$ acres a year carried on uninterruptedly for 81 years. To reforest the $81,000,000$ acres of hopelessly denuded land which should be growing timber both because it is needed and also because this land is fit for nothing else would require at the rate provided for in the Snell Bill 810 years and an original outlay of $\$ 810$,000,000 . Now about 130 years are required to produce good merchantable saw-timber, and 30 to 40 years to produce pulp wood. If compound interest be computed on the capital required for such an undertaking for 40 to 130 years the unsophisticated may begin to understand why tree planting as a process of restoring forest lands is relatively a minor matter in the minds of foresters. A forester never plants trees if he can get Nature to do it for him. Furthermore, Nature, if given half a chance, will usually do it. Planting is the most expensive method of establishing a new stand of timber. It involves a relatively high initial investment which must be carried at compound interest during the entire period required for the timber crop to grow to merchantable size and to be harvested. When it is remembered that the $81,000,000$ acres referred to as utterly denuded is but a fraction of the total acreage utterly denuded is but a fraction of the total acreage
requiring attention it will readily be seen that something besides planting is required if the country is to have a timber supply at all commensurate with its needs a few years hence.

That something is fire protection. According to a statement by Col. W. B. Greeley, Chief Forester, of the U. S. Forest Service, 39 States contain approximately $325,000,000$ acres of timbered and cut over land in State and private ownership requiring protection from fire, which is the first step toward providing a continuous supply of timber. Of this area $175,000,000$ acres are almost wholly unprotected. There are from ten tinousand to twenty-five thousand forest fires every year which destroy the young forest growth on eight to ten million acres every year, aside from large areas burned over annually of which no record can be obtained.

Effective protection of these $325,000,000$ acres of forest land, according to Col. Greeley, lies at the bottom of any National policy of reforestation. Once this vast area is really protected from forest fires, three-fourths of our timber supply problem will be solved.

Since 1911 the U. S. Forest Service has cooperated in fire protection work in 10 to 25 States, expending from $\$ 40,000$ to $\$ 125,000$ per year of Federal funds. In that period State and county expenditures have increased from about $\$ 250,000$ a year to more than a million dollars while private expenditures have increased six or eight fold.

The cost of protecting forest lands from fire as reported by 26 States averages $21 / 2$ cents an acre. A forest protection budget for the United States, excluding National forests, would thus aggregate about $\$ 8,125,000$ a year, whereas the sums reyear, whereas the sums regularly available aggregate $\$ 1,885,000$, of which State
and county appropriations represent $\$ 1,060,000$, private expenditures $\$ 700,000$ and the Federal appropriation $\$ 125,000$ In other words only about 25 per cent of the necessary task of protecting forest lands from fire is being done today.

"Forest fires, particularly those caused by lightning," said Assistant Forester E. E. Carter, "can not be entirely eliminated, nor can mancaused forest fires be eliminated any more than can man-

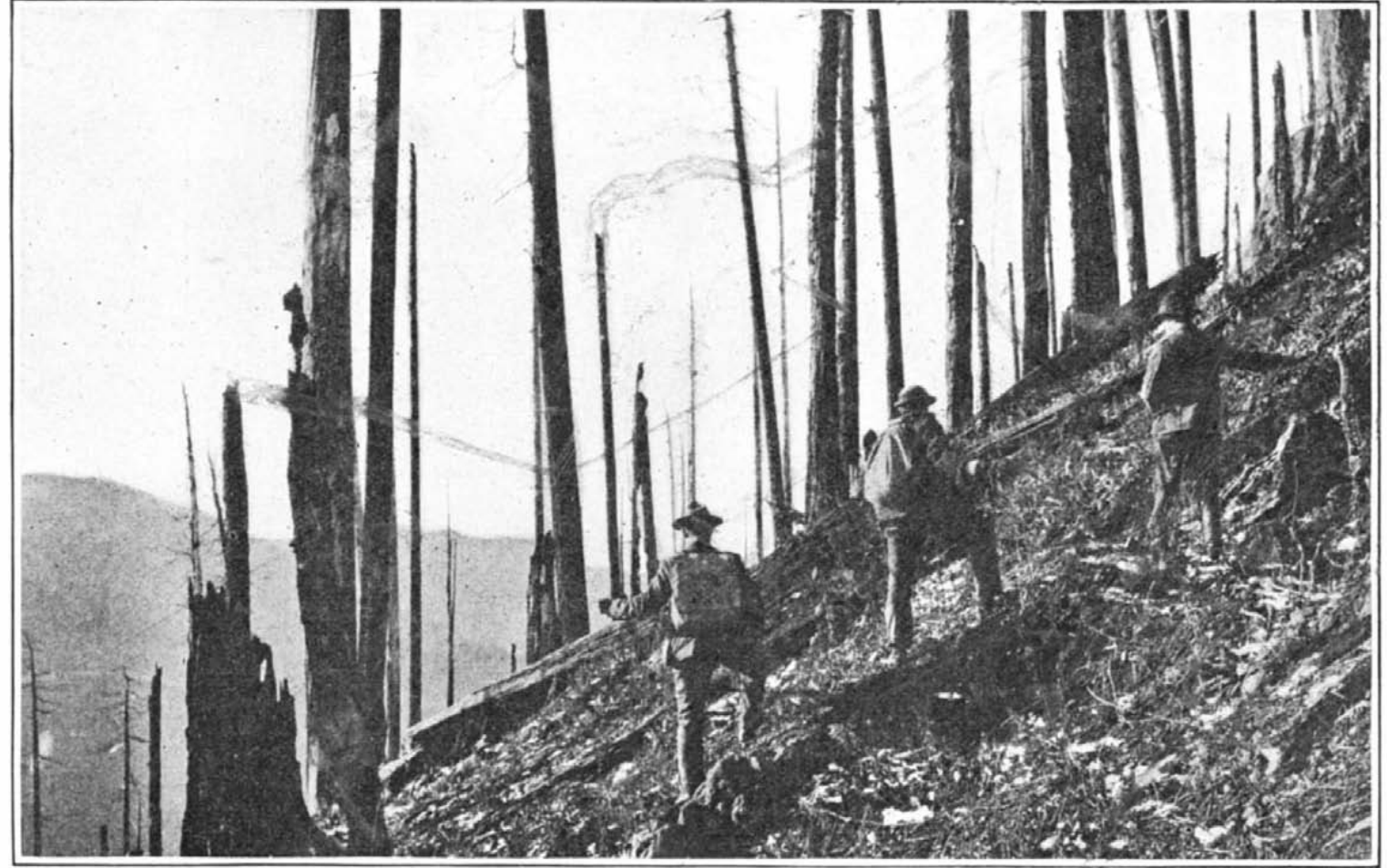

Broadcast seeding on high ridges in the wake of forest fires, Olympic National Forest, Washington

caused fires in cities. In its essentials the problem of orest fires differs only in degree from the problem of man-caused city fires. The first essential is the recognition by every one of the danger and of the community loss from forest fires. The second is an organization to put out those which do occur while they are yet small. In some regions recognition of the serious los the community as well as to the land owner resulting from forest fires has not been developed. As result fire fighting is more costly than will be necessar after the public is aroused. In some of the Western National forests a smaller force is now needed for fire protection just because the local public has acquired enlightened point of view regarding forest fires and has accu

"Forest fire protection, in my judgment, will reforest or keep cut-over land growing forest on hundreds of acres for every acre that has been or is likely to be eforested by planting. If fire protection alone will not restock the land with a new crop of trees a new crop can in many places be secured by leaving seed trees or in some types of forests by leaving the smaller trees when the mature crop is cut. Planting will have to be resorted to to reestablish forests on areas so

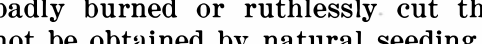

"Part of the $81,000,000$ acres so devastated by reckless cutting and by fire that it is no longer productive will have to be planted. Fire protection alone will restore the remainder. "There wilt be little excuse for extensive planting outside these devastated areas. The exceptions will be where the need exists of securing quick indirect benefits such as the prevention of erosion, or in the Nebraska sand hills, or where local economic conditions justify extra expense to assure full stocking quickly."

The Snell Bill appropriates $\$ 1,000,000$ a year for fire protection in cooperation with States and through them with private agencies. In the Pacific Northwest there are some thirty organizations of timber owners
cooperating with each other and with the State and cooperating with each other and with the State and 